\title{
Production and physicochemical characterization of craft beer with ginger (Zingiber officinale)
}

\author{
Luciano Moro TOZETTO ${ }^{1}$, Revenli Fernanda do NASCIMENTO ${ }^{1 \star}$ (D), Mariel Hang de OLIVEIRA², \\ Junior VAN BEIK ${ }^{3}$, Maria Helene Giovanetti CANTERI ${ }^{1}$
}

\begin{abstract}
This work aims to produce and to characterize physical-chemically an added craft beer of ginger, as well as its sensorial attributes, due to the new demand for products with innovative flavors. The traditional method of production of beer craft type Pilsen was used, with addition of $2 \mathrm{~g} \mathrm{~L}^{-1}$ of ginger chips in the maturation stage. The final product presented alcoholic content of $3.40^{\circ} \mathrm{GL}$, primitive extract of $7.81^{\circ} \mathrm{P}$, real degree of fermentation of $68.71 \%$, energy value of $115 \mathrm{KJ} \mathrm{mL}-1$, bitterness of 21.5 B.U, $\mathrm{pH}$ of 4.46 and color of 7.13 E.B.C. Regarding the minerals, it presented $\left(\mathrm{mg} \mathrm{L}^{-1}\right) 58.4$ of magnesium; 21.2 of sodium; 412.5 of potassium; 0.06 of iron; 0.23 of copper and 0.04 of zinc. In the sensorial evaluation, the index of global acceptability was of $92 \%$, being others appraised attributes (color, flavor, aroma, appearance and bitterness) with index above $70 \%$. As for the purchase intention, most of the fitting room indicated that they would buy (91\%). A chemometric approach indicated that our beer added of ginger showed different characteristics from the others samples classified as pure malt, due to the alcohol, apparent and real degrees of fermentation, energy, potassium and magnesium contents.
\end{abstract}

Keywords: craft beer; agroindustrial innovation; Zingiber officinale.

Practical Application: The craft beer production method as well as the quality control parameters analyzed can be used by micro-breweries, contributing to increase innovation capacity and the quality of the final product.

\section{Introduction}

Beer is a beverage obtained through alcoholic fermentation of the malted cereal's wort (Dallacort, 2013), used as human food since 8000 b. C. (Pinto et al., 2015), becoming the most consumed beverage worldwide after water and tea (Nelson \& Cox, 2014). One of the major consumers of beer, Brazil occupies third place, having consumed approximately 14 billion liters in 2014, representing 62 liters per capita (Serviço Brasileiro de Apoio às Micro e Pequenas Empresas, 2014), of which the Pilsner type beer is the absolute leader in the Brazilian market preference, corresponding to $98 \%$ of the total consumed (Pinto et al., 2015).

With the growing beer market expansion, special beers have emerged, known as craft beer (Oliveira \& Silva, 2017), garnering a market share of major breweries (Murray \& O’Neill, 2012) because of their strong flavor and aroma associated with a high quality standard, coming from a careful selection of raw materials and changes in manufacturing processes, such as changes in the times and temperatures of mashing, fermentation and maturation (Aquilani et al., 2015). At the same time, consumers of craft beers are becoming more demanding when choosing products, preferring those with innovative flavor and aroma, regarded as the most important attributes in beer (Rendall et al., 2015).

To meet these consumers' demands, craft beer manufacturers have been betting on the use of distinct ingredients such as rice, honey, fruits, cassava, pumpkin, herbs, and ginger, among other agents, in order to cause positive sensory changes on the final product (Pinto et a., 2015; Rio, 2013; Brunelli \& Venturini, 2013; Brunelli et al., 2014; Matsubara et al., 2016).

Ginger (Zingiber officinale Roscoe) is an herbaceous plant belonging to the family Zingiberaceae, widely grown in tropical and subtropical regions (Haniadka et al., 2013). Rhizomes are the most important part of the plant, frequently used to enhance the flavor and aroma of food (Peter, 2006) and used for pharmaceutical purposes, due to the high amount of bioactive compounds (Tohma et al., 2017). The ginger's distinct aroma originates from the presence of volatile compounds, such as camphene, geranyl acetate, borneol, geraniol, limonene, and gingerol, among other terpenes, whereas non-volatile molecules are responsible for the sharp, hot feeling in the mouth (Haniadka et al., 2013; Peter, 2006). This is the main attribute of interest of using ginger in the food industry as raw material for the manufacture of alcoholic beverages, sodas, soft drinks, bakery products, condiments, preserves, among others (Ravindran \& Babu, 2005).

Based on the above, this study aimed to produce and characterize physiochemically a craft beer with ginger (Zingiber officinale) in comparison to commercial beers, as well as to assess the sensory attributes and the purchase intention of the product developed. 


\section{Material and methods}

\subsection{Material}

For the production of the Pilsner type craft beer with ginger, which will be called henceforth in this study as Pós Beer, were used: fresh ginger (Zingiber officinale Roscoe) purchased in local shops of the city of Ponta Grossa-PR, first generation Saflager yeast W-34/70 (Fermentis, S. I. Lesaffre, France), pelleted hops types Perle and Nugget (Hallertau, Germany), Pilsner malt (Weyermann $^{\circledR}$ ) and sugar (sucrose) of type Crystal (Certano ${ }^{\circledR}$ ), and Whirflock flocculant acquired in a resale of supplies for craft brewers in the City of Ponta Grossa-PR.

For comparative purposes, 28 beer samples were acquired in supermarket chains in the region of Campos Gerais/PR, in the first half of the year of 2016.

\subsection{Production of the craft beer with ginger}

For the product's development, the traditional method for brewing Pilsner craft beer was used. A volume of $15 \mathrm{~L}$ of water with pH 6.3 from an artesian well of the Federal University of Technology - Paraná, Ponta Grossa Campus (UTFPR, PG), was heated to $50{ }^{\circ} \mathrm{C}$ and mixed with $5 \mathrm{~kg}$ of malt previously malted in a manual disc mill (Guzzo). This mixture remained at $50{ }^{\circ} \mathrm{C}$ for $30 \mathrm{~min}$, then slow heating $\left(1^{\circ} \mathrm{C} \mathrm{min}^{-1}\right)$ was executed until it reached $62^{\circ} \mathrm{C}$, and then it was left standing for 30 minutes more. The slow heating process was done again up to $75^{\circ} \mathrm{C}$ and the mixture was left standing for $10 \mathrm{~min}$. Later, the process of saccharification of starch was analyzed by Lugol test (Tschope, 2001), which, once resulting in negative, allowed for the substance to be called wort.

The wort was subjected to the clarification process, run by recirculation in a lauter tun with false bottom at a temperature of $75{ }^{\circ} \mathrm{C}$, followed by wort wash (sparging). Afterwards, the wort $(45 \mathrm{~L})$ was heated until boiling point and, after $10 \mathrm{~min}$, $15 \mathrm{~g}$ of hops type Nugget were added to it to give bitterness to the product. After $50 \mathrm{~min}$ of vigorous boiling, $40 \mathrm{~g}$ of type Perle hops were added in order to enhance the aroma of the beverage. At the end of $80 \mathrm{~min}$ of boiling, the wort was stirred vigorously counterclockwise with a beer stirring paddle making a vortex movement, having two pills of flocculant added, let to rest for $20 \mathrm{~min}$ for the formation of the trub. After having the wort cooled with the aid of a copper coil, it was unloaded into the fermentation tank, taking care not to drag the trub with the wort.

For the fermentation process, the yeast (23 g), which was previously rehydrated in $100 \mathrm{~mL}$ of water that was boiled and then cooled to a temperature of $20^{\circ} \mathrm{C}$ for one hour, was added to the wort, over which vigorous aerating was unleashed for at least 8 minutes before yeast dosage, in order to get to the range of 8 to $10 \mathrm{ppm}$ of dissolved oxygen in the wort. The airlock valve was adapted in the upper output of the fermentation tank, in constant $10{ }^{\circ} \mathrm{C}$ temperature for $240 \mathrm{~h}$. Having concluded this fermentation process, the yeast was removed, performing the transfer of wort to another fermenter.

To initiate the process of maturation, the wort was cooled down to $4^{\circ} \mathrm{C}$ and was added $80 \mathrm{~g}$ of ginger, previously sanitized in hypochlorite solution $2 \% \mathrm{v} / \mathrm{v}$ and washed in running water, cut in slivers of $1 \mathrm{~cm}^{2}$. The amount of ginger added was defined based on the study by Ferreira et al. (2013).

For bottling, a solution of $7 \mathrm{~g} \mathrm{~L}^{-1}$ of sugar was added to the crude beer, followed by homogenizing and sealing with a cork. The beer remained at room temperature for 7 days in a dark room for the process of secondary carbonation. The beer did not pass through the pasteurization and filtration processes for its bottling, as typically occurs with commercial products. A label was developed for the product created containing its basic information: fabrication date, expiration date, alcohol content, ingredients, producer identification and warning phrases.

In Figure 1, the manufacturing process of craft beer with ginger, pointing the moment ginger was added.

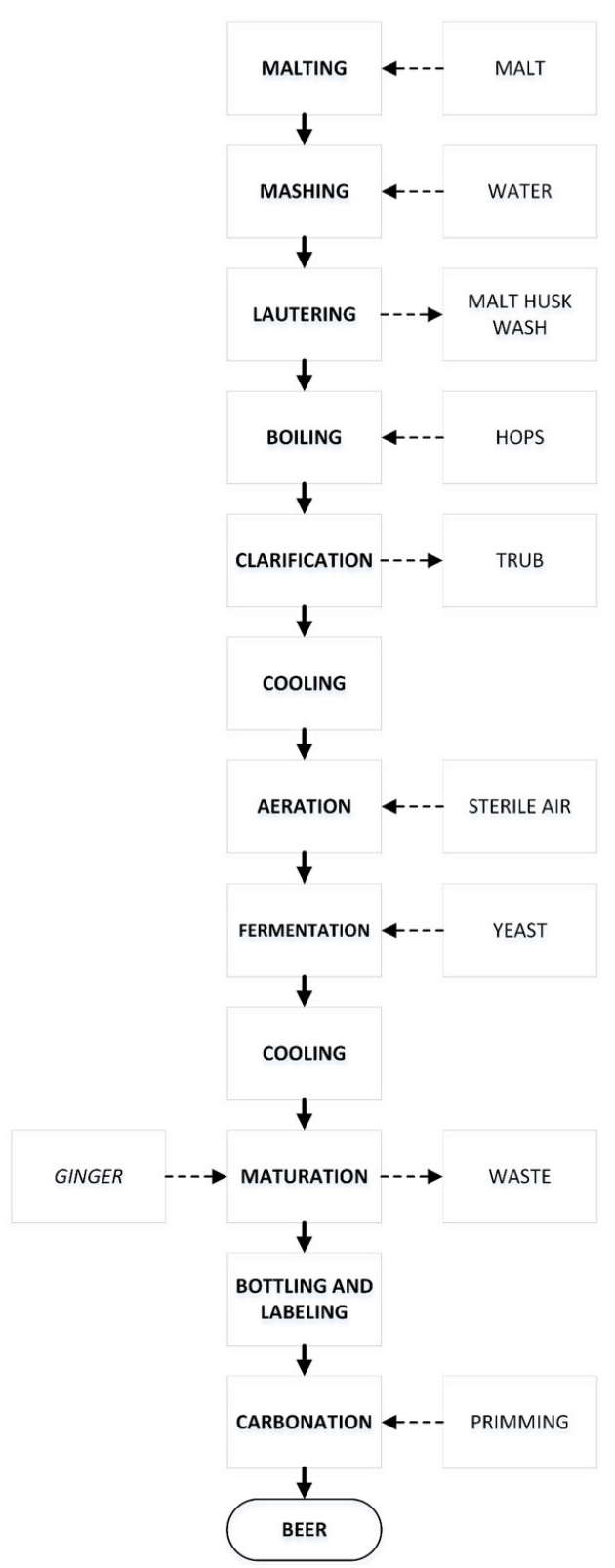

Figure 1. Diagram of manufacturing process of craft beer with ginger. 


\subsection{Physicochemical characterization}

Determinations carried out with the beer analyzer equipment

For alcohol determination (\%v/v), primitive extract ( $\left.{ }^{\circ} \mathrm{Plato}\right)$; real degree of fermentation (RDF\%), apparent degree of fermentation $(\mathrm{ADF} \mathrm{m} / \mathrm{m})$, energy value $\left(\mathrm{KJ} / 100 \mathrm{ml}^{-1}\right)$ and alcohol $(\% \mathrm{~m} / \mathrm{m})$ the near infrared measurement technique (NIR) was used, in specific equipment for beer analyses, Beer Analyser model DSA 5000 (Anton-Paar, Austria) (Dragone et al., 2007), kindly provided by a brewery from the city of Ponta Grossa-PR. All the measurements were performed in triplicate, by injected into the Beer Analyzer $50 \mathrm{~mL}$ of each sample previously decarbonated and filtered on filter paper and finally read.

\section{Bitterness determination}

Bitterness was determined through extraction of the substances responsible for the hops' bitterness, the alpha and beta acids with isooctane (2,2,4-trimethylpentane). In order to determine this, $20 \mathrm{~mL}$ of each sample previously acidized with help of $0.5 \mathrm{~mL}$ of $\mathrm{HCl} 6.0 \mathrm{~mol} \mathrm{~L}^{-1}$ was mixed with $20 \mathrm{~mL}$ of isooctane. Next, wavelength readings at $275 \mathrm{~nm}$ in spectrophotometer (DR 5000) were performed with use of a $10 \mathrm{~mm}$ quartz cuvette, as per methodology described by Philpott, Taylor and Williams (Philpott et al., 1997). The results were calculated through Equation 1 and expressed in Bitterness Units (B.U.).

Abs $275 \mathrm{~nm} * 50=$ Bitterness $($ B.U. $)$

\section{Color determination}

For determination of color intensity, the spectrophotometric method 8.5 Analytica - EBC (European Brewery Convention, 2005 ) was used. The samples were filtered in a $0.45 \mathrm{~nm}$ membrane filter and then absorbance reading at $430 \mathrm{~nm}$ was performed with the use of a $10 \mathrm{~mm}$ glass cuvette. The results were found through Equation 2, where $\mathrm{A}$ is absorbance at $430 \mathrm{~nm}$.

$A * 25=C O L O R(E B C)$

\section{Determination of $p H$}

The $\mathrm{pH}$ value of the samples were determined in a digital apparatus of the commercial brand Quimis (model Q400BD), according to methodology of the Instituto Adolfo Lutz (2008)

\section{Mineral analysis}

For quantification of the levels of magnesium, sodium, potassium, copper, iron, and zinc in the samples, all reagents adopted were of analytical grade, and the solutions of nitric acid $\left(\mathrm{HNO}_{3}\right) 65 \%$ at v v ${ }^{-1}$ (Merck - Germany) and hydrogen peroxide $\left(\mathrm{H}_{2} \mathrm{O}_{2}\right)$ at $35 \% \mathrm{v} \mathrm{v}^{-1}$ (Vetec, Brazil) were prepared in glassware previously decontaminated through wash of $\mathrm{HNO}_{3} 10 \% \mathrm{vv}^{-1}$ for $24 \mathrm{~h}$, using ultrapure water with resistivity of $18 \mathrm{M} \Omega \mathrm{cm}$ (Master System MS 2000, GEHAKA) for cleaning of the glassware as well as for preparing the solutions.

Initially, the samples were subjected to acid digestion through wet medium, wherein $20 \mathrm{~mL}$ of each sample was transferred to
Kjeldahl tubes, followed by the addition of $3 \mathrm{~mL}$ of $\mathrm{HNO}_{3}$ and $2 \mathrm{~mL}$ of $\mathrm{H}_{2} \mathrm{O}_{2}$. Afterwards, the tubes were submitted to heating in block digester (SL 25/40, SOLAB, Brazil) at a temperature of $80^{\circ} \mathrm{C}$ for 30 minutes and then at $120^{\circ} \mathrm{C}$ for another $1 \mathrm{~h}$ and $20 \mathrm{~min}$. After digestion, the samples were enlarged to $50 \mathrm{~mL}$ in volumetric flasks. Quantification of sodium and potassium was performed for flame photometry with the Analyser 910MS photometer, calibrated with standard solution containing $100 \mathrm{mg} \mathrm{L}^{-1}$ of each of the analytes. For determination of copper, iron, zinc and magnesium, using the atomic absorption spectrometer with flame atomization (FAAS) AAnalyst 700 (Perkin Elmer-Sciex, Canada) equipped with a S10 automatic sampler. For the readings, hollow cathode lamps were used in the copper, iron, zinc and magnesium varieties, with wavelengths of $324.8 \mathrm{~nm}$, $248.3 \mathrm{~nm}, 248.3 \mathrm{~nm}$ and $213.9 \mathrm{~nm}$ respectively, monitored in $0.7 \mathrm{~nm}$ spectral slit. For determination of copper, a flame composed of air-acetylene $\left(2: 14 \mathrm{~L} \mathrm{~min}^{-1}\right)$ was used; for iron and magnesium, air-acetylene $\left(2.2: 8 \mathrm{~L} \mathrm{~min}^{-1}\right)$, and for zinc, air-acetylene $\left(2: 14 \mathrm{~L} \mathrm{~min}^{-1}\right)$. Reading times for copper and zinc were of 4 seconds, and for iron and magnesium, 3 seconds.

\subsection{Sensory analysis}

Sensorial evaluation of beer was performed in accordance with the approval of the Research Ethics Committee (CEP UTFPR; CAAE 57125716.5.0000.5547). 85 untrained tasters with age over 18 years, selected by prior screening that indicated consumption of Pilsner type beer at least once a week, and who had no aversion to ginger, participated in the experiment. The attributes evaluated were color, taste, aroma, bitterness and appearance, assessed with the hedonic scale of nine points, and purchase intent, assessed with structured five-point scale. The Acceptability index of the product was calculated using Equation 3, where A represents the average grade of the product, and $\mathrm{B}$ the maximum grade given to the product.

$$
I A(\%)=A \times 100 / B
$$

\subsection{Multivariate analysis}

Due to the large number of samples of the parameters analyzed, it was necessary the use of a statistical tool to enable dimensionality reduction of the array of results without losing relevant information, through the use of Principal Components Analysis (PCA) (Martens \& Naes, 1991).

The comparison between beer samples with a chemometrical application through principal component analysis (PCA) and hierarchical cluster analysis (HCA) was performed with the Pirouette 4.5 software (Infometrix, USA). The data were previously auto scaled before being subjected to analyses for equalizing the statistical importance of all variables (Granato et al., 2014). From the results obtained, graphics of the scores were generated with the principal components (PC) and the weights (loadings). For obtaining the dendrogram of the HCA, Euclidean distance and incremental connection method were used.

An array of 29 samples and 8 variables (alcohol content, apparent extract, real degree of fermentation, apparent degree of fermentation, calories, sodium, magnesium and potassium) was 
constructed, in which samples were taken as rows and variables as columns, totaling 232 data points. The samples were classified according to the raw material used in the production, between pure malt $(\mathrm{n}=15$, among which is included the sample of craft beer with ginger) and beer $(n=14)$.

\section{Results and discussion}

\subsection{Physicochemical characterization}

In Table 1, the results of physicochemical analyses carried out on the beer samples are shown, of which the first sample represents the analytical data of the Pós Beer, the craft beer with ginger.

According to the decree No. 6,871 of 2009 (Brasil, 2009), beers can be classified according to: alcohol content, as without alcohol $(<0.5 \% \mathrm{v} / \mathrm{v})$ and with alcohol $(>0.5 \% \mathrm{v} / \mathrm{v})$; primitive extract, as lightweight (5 to $10.5 \%$ ), beer (10.5 to $12.0 \%$ ), extra (12.0 to $14.0 \%)$ and strong (> 14\%); color, as clear (<20 EBC),

dark (> 20 EBC), and colorful (different from EBC standards); proportion of malted barley, as pure malt (100\%) and beer $(\geq 50 \%)$.
Thus, the Pilsner type beer with ginger (Pós Beer) produced in this work is classified as alcoholic $(3.4 \% \mathrm{v} / \mathrm{v})$, light, clear and pure malt. Rio (2013), when characterizing an Ale type beer formulated with ginger (Zingiber officinalis) and Brazilian mint (Mentha arvensis), classified it as alcoholic (5.5\% v/v) and extra in regards to primitive extract (15.73\%). Among the commercial samples analyzed in this study, one featured alcoholic content below $4 \% \mathrm{v} / \mathrm{v}$, six featured above $5 \% \mathrm{v} / \mathrm{v}$, and the remainder featured between 4 and $5 \% \mathrm{v} / \mathrm{v}$; as for the primitive extract, five beer samples were classified as light, twenty as beer and three as extra; as for the color, only one sample was classified as dark beer; as for malt proportion, fourteen samples were classified as pure malt and the rest were classified as beer. Olšovská et al. (2015), when analyzing 34 Lager type beer samples in the Czech Republic, have reported average alcohol content of $3.8 \% \mathrm{v} / \mathrm{v}$. In 27 samples of Chinese canned beer, average alcohol content remained between 2.5 and $4.3 \% \mathrm{v} / \mathrm{v}$ and primitive extract remained between 8 and $12{ }^{\circ}$ Plato (Tan et al., 2015).

The degree of fermentation is a measure of the transformation of sugar contained in wort into alcohol and $\mathrm{CO}^{2}$. The apparent degree of fermentation (ADF) expresses the amount of the extract

Table 1. Average results of physicochemical analyses carried out on Pós Beer and beer samples purchased in local shops of the city of Ponta Grossa-PR.

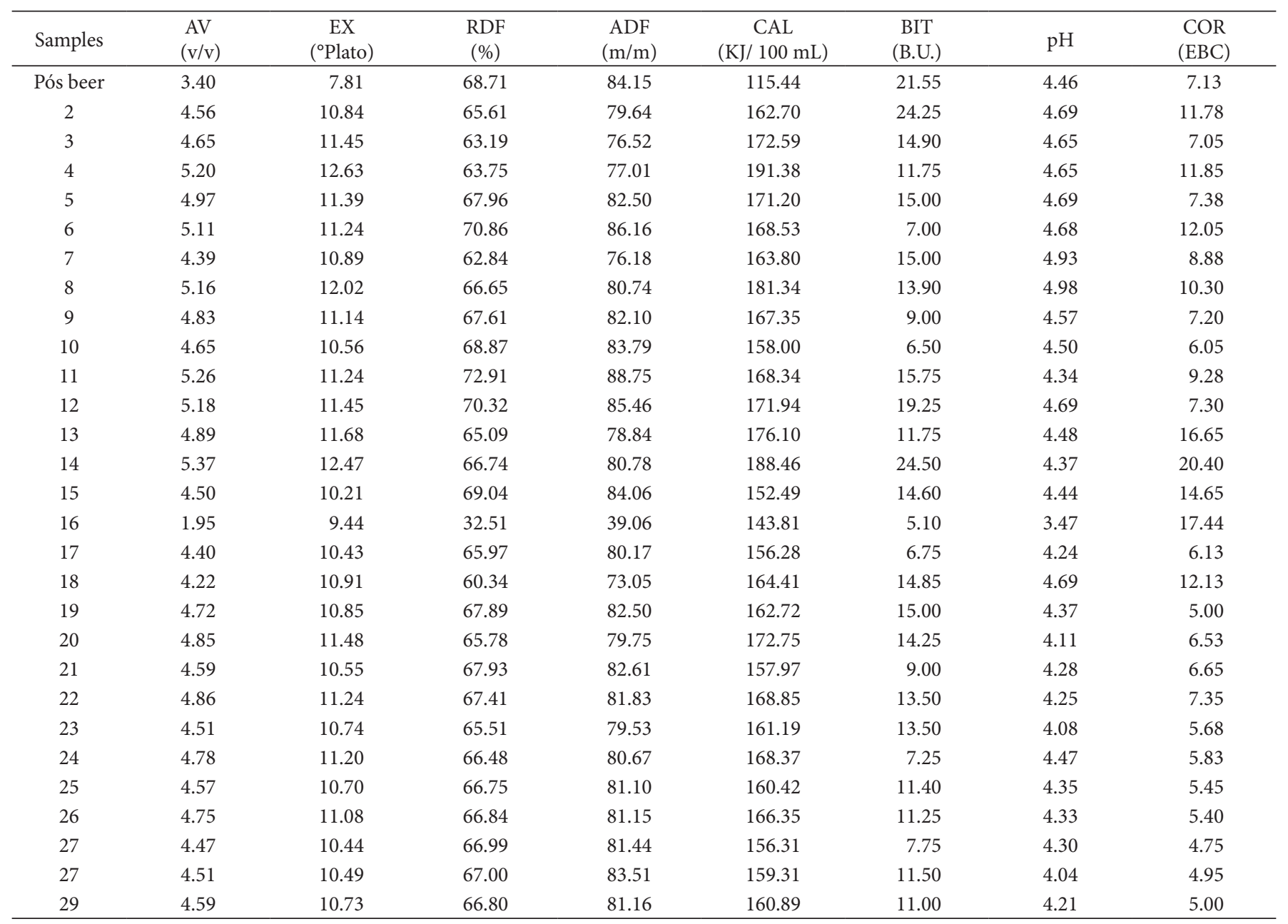

Abbreviations: AV - alcohol content expressed in volume; EX - extract; RDF - real degree of fermentation; ADF - apparent degree of fermentation; CAL - calories; BIT - bitterness; $\mathrm{pH}$ - hydrogen potential. 
fermented, considering the presence of alcohol. The real degree of fermentation (RDF) does not consider the presence of alcohol, thus indicating the real value of conversion (Kunze, 2006). In this study, the ADF values of the samples were shown to be $16 \%$ higher than those of the RDF. According to Nielsen and Erdal (Neilson \& Erdal, 2005) the beers feature RDF between 65 and 85\%; thus, considering this basis, only five samples $(3,4,7,16$ and 18$)$ have lesser values than $65 \%$. Andrade et al. (2016), when assessing the quality of different brands of Pilsner type beer, reported RDF between 59.02 and $69.44 \%$.

According to Decree No. 6,871 of 2009 (Brasil, 2009), the energy value of the beer ready for consumption should have a maximum

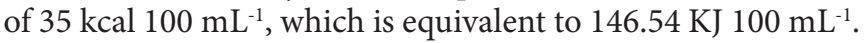

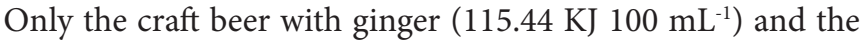

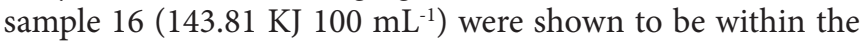
established in the decree. Brunelli \& Venturini (2013) reported on average $131.32 \mathrm{KJ} \mathrm{mL}^{-1}$ for the energy value of craft beer prepared with honey.

The typical bitterness of beers stems from iso-alpha-acids, which quantitatively constitute the most important fraction of hops. However, the real bitterness perceived by the beer consumers is widely modified by complexation with residual sugars, which makes the bitterness pleasant to them (Keukeleire,
2000). The bitterness of the samples analyzed varied between 5.10 and 24.5 B.U., depending on the desired sensory characteristics of each beer. Schmidt et al. (2014) produced beers presenting between 28 and 33 B.U. Brunelli et al. (2014) found average bitterness between 11.71 and 9.79 B.U. for beers produced with 20 and $30 \%$ of honey, respectively.

The $\mathrm{pH}$ of the beers analyzed was situated between 3.47 and 4.98, in accordance with Rebello (2009), who states beer has a pH of around 4.0. Results similar to those found for the Pós Beer developed in this work (4.46) were reported by Matsubara et al. (2016), which found a pH of 4.27 for wheat craft beer with ginger, as well as by Pinto et al. (2015), with pH of 4.24 for craft beer with acerola and pineapple.

In Table 2, results of the mineral analyses for each sample are listed, the first being that of the craft beer with ginger (Pós Beer) produced in this study.

It is observed that the mineral with greatest concentration in all samples analyzed was potassium ( 325 to $850 \mathrm{mg} \mathrm{L}^{-1}$ ), followed by magnesium ( 48.22 to $95.66 \mathrm{mg} \mathrm{L}^{-1}$ ) and sodium (11.25 to $137.50 \mathrm{mg} \mathrm{L}^{-1}$ ). In regards to this relatively high proportion of potassium: sodium in beer stimulates ionic pump activity of sodium-potassium-ATPase, contributing to the balance of these minerals in the body (Nascimento et al., 2017; Tomazoni \&

Table 2. Quantity of minerals (magnesium, sodium, potassium, iron and zinc) present in beer samples purchased in local shops of the city of Ponta Grossa-PR and Pós Beer.

\begin{tabular}{|c|c|c|c|c|c|c|}
\hline Samples & Magnesium $\left(\mathrm{mg} \mathrm{L}^{-1}\right)$ & Sodium $\left(\mathrm{mg} \mathrm{L}^{-1}\right)$ & Potassium $\left(\mathrm{mg} \mathrm{L}^{-1}\right)$ & Copper $\left(\mathrm{mg} \mathrm{L}^{-1}\right)$ & Iron $\left(\mathrm{mg} \mathrm{L}^{-1}\right)$ & $\operatorname{Zinc}\left(\mathrm{mg} \mathrm{L}^{-1}\right)$ \\
\hline Pós Beer & 58.43 & 21.25 & 412.50 & 0.23 & $<0.06$ & 0.04 \\
\hline 2 & 74.91 & 22.50 & 625.00 & $<0.01$ & $<0.06$ & 0.06 \\
\hline 3 & 80.91 & 137.50 & 600.00 & $<0.01$ & 1.94 & 0.03 \\
\hline 4 & 72.12 & 37.50 & 850.00 & $<0.01$ & 1.25 & 0.01 \\
\hline 5 & 74.50 & 62.50 & 687.50 & 0.39 & 0.56 & 0.08 \\
\hline 6 & 89.38 & 37.50 & 725.00 & 0.26 & 0.69 & 0.01 \\
\hline 7 & 69.16 & 62.50 & 712.50 & 0.68 & $<0.06$ & 0.02 \\
\hline 8 & 79.01 & 37.50 & 675.00 & 0.21 & 0.35 & $<0.003$ \\
\hline 9 & 85.16 & 25.00 & 675.00 & 0.55 & $<0.06$ & $<0.003$ \\
\hline 10 & 76.40 & 25.00 & 675.00 & 0.55 & $<0.06$ & 0.01 \\
\hline 11 & 79.11 & 25.00 & 625.00 & 0.50 & $<0.06$ & $<0.003$ \\
\hline 12 & 78.51 & 50.00 & 637.50 & 0.26 & 0.56 & 0.04 \\
\hline 13 & 92.52 & 75.00 & 700.00 & $<0.01$ & $<0.06$ & 0.02 \\
\hline 14 & 95.66 & 37.50 & 687.50 & $<0.01$ & $<0.06$ & $<0.003$ \\
\hline 15 & 84.41 & 25.00 & 562.50 & $<0.01$ & $<0.06$ & $<0.003$ \\
\hline 16 & 48.22 & 11.25 & 412.50 & $<0.01$ & $<0.06$ & 0.05 \\
\hline 17 & 58.56 & 21.25 & 387.50 & $<0.01$ & $<0.06$ & 0.03 \\
\hline 18 & 65.16 & 125.00 & 600.00 & $<0.01$ & $<0.06$ & 0.08 \\
\hline 19 & 65.65 & 12.50 & 475.00 & 0.07 & $<0.06$ & 0.1 \\
\hline 20 & 62.46 & 100.00 & 387.50 & 0.18 & $<0.06$ & 0.07 \\
\hline 21 & 64.50 & 87.50 & 375.00 & $<0.01$ & $<0.06$ & 0.29 \\
\hline 22 & 85.20 & 62.50 & 600.00 & $<0.01$ & $<0.06$ & $<0.003$ \\
\hline 23 & 45.07 & 125.00 & 325.00 & $<0.01$ & $<0.06$ & $<0.003$ \\
\hline 24 & 67.74 & 125.00 & 400.00 & $<0.01$ & $<0.06$ & 0.02 \\
\hline 25 & 53.54 & 87.50 & 325.00 & $<0.01$ & $<0.06$ & 0.01 \\
\hline 26 & 59.83 & 62.50 & 462.50 & $<0.01$ & $<0.06$ & $<0.003$ \\
\hline 27 & 49.34 & 50.00 & 437.50 & $<0.01$ & $<0.06$ & $<0.003$ \\
\hline 28 & 49.18 & 25.00 & 375.00 & $<0.01$ & $<0.06$ & $<0.003$ \\
\hline 29 & 56.05 & 50.00 & 412.50 & $<0.01$ & $<0.06$ & $<0.003$ \\
\hline
\end{tabular}


Saviero, 2009). Alcázar et al. (2002), when quantifying the mineral content of 32 samples of Lager type beer from Spain, found values for potassium between 304.9 and $495.7 \mathrm{mg} \mathrm{L}^{-1}$, for magnesium between 43.10 and $266.59 \mathrm{mg} \mathrm{L}^{-1}$, and for sodium between 8.36 and $103.03 \mathrm{mg} \mathrm{L}^{-1}$. In smaller amounts, the following was found: zinc $\left(<0.003\right.$ to $\left.0.29 \mathrm{mg} \mathrm{L}^{-1}\right)$, copper $\left(<0.01\right.$ to $\left.0.68 \mathrm{mg} \mathrm{L}^{-1}\right)$ and iron $\left(<0.06\right.$ to $\left.1.94 \mathrm{mg} \mathrm{L}^{-1}\right)$. Ubuoh et al. (2013) mentioned values between 0.07 and $0.15 \mathrm{mg} \mathrm{L}^{-1}$ for zinc, between 0.04 to $0.08 \mathrm{mg} \mathrm{L}^{-1}$ for copper and 0.23 to $0.56 \mathrm{mg} \mathrm{L}^{-1}$ for iron, in Nigerian canned beers. Higher values were reported by Nascentes et al. (2005) for zinc and copper in samples of Brazilian beers, 0.17 to $0.19 \mathrm{mg} \mathrm{L}^{-1}$ and 0.13 to $0.16 \mathrm{mg} \mathrm{L}^{-1}$, respectively.

Figure 2 shows comparative graphs of minerals between samples classified as pure malt and beer. It is observed that statistically significant differences were found between the two groups of samples, considering a significance level of 5\% (Ftabled $=4.21$ ) for magnesium (Fcalculated $=29.32)$, potassium $($ Fcalculated $=47.38)$ and copper (Fcalculated=7.24). For sodium (Fcalculated $=2.68$ ), iron (Fcalculated $=0.33$ ), and zinc (Fcalculated $=0.74$ ) there were no significant differences.

\subsection{Sensory analysis}

It is noteworthy that the team of tasters was composed of a group of untrained people, although about half of this population considered themselves beer connoisseurs. The hypothesis proposed was that the beer with ginger would show an acceptability index above $70 \%$. The results indicated the Acceptability index values of the product were of $95 \%$ for color, $90 \%$ for taste, $90 \%$ for aroma, $86 \%$ for bitterness, $96 \%$ for appearance and $92 \%$ for global acceptance. The beer with ginger presented generally good sensory acceptance of visual aspects such as color and appearance, in addition to flavor and aroma. The notes obtained in this study were higher than those reported by Costa (2016) for the same sensory attributes, except for bitterness (not rated) in samples of light beer with low alcohol content, as well as higher than those mentioned by Pinto et al. (2015) for craft beer processed with pineapple and acerola.

However, the sense of bitterness resulted in a lower rate of acceptability (86\%) compared to other attributes. The average of the values for this attribute in this experiment was 7.72. Interestingly, it is believed that, because the team was composed of

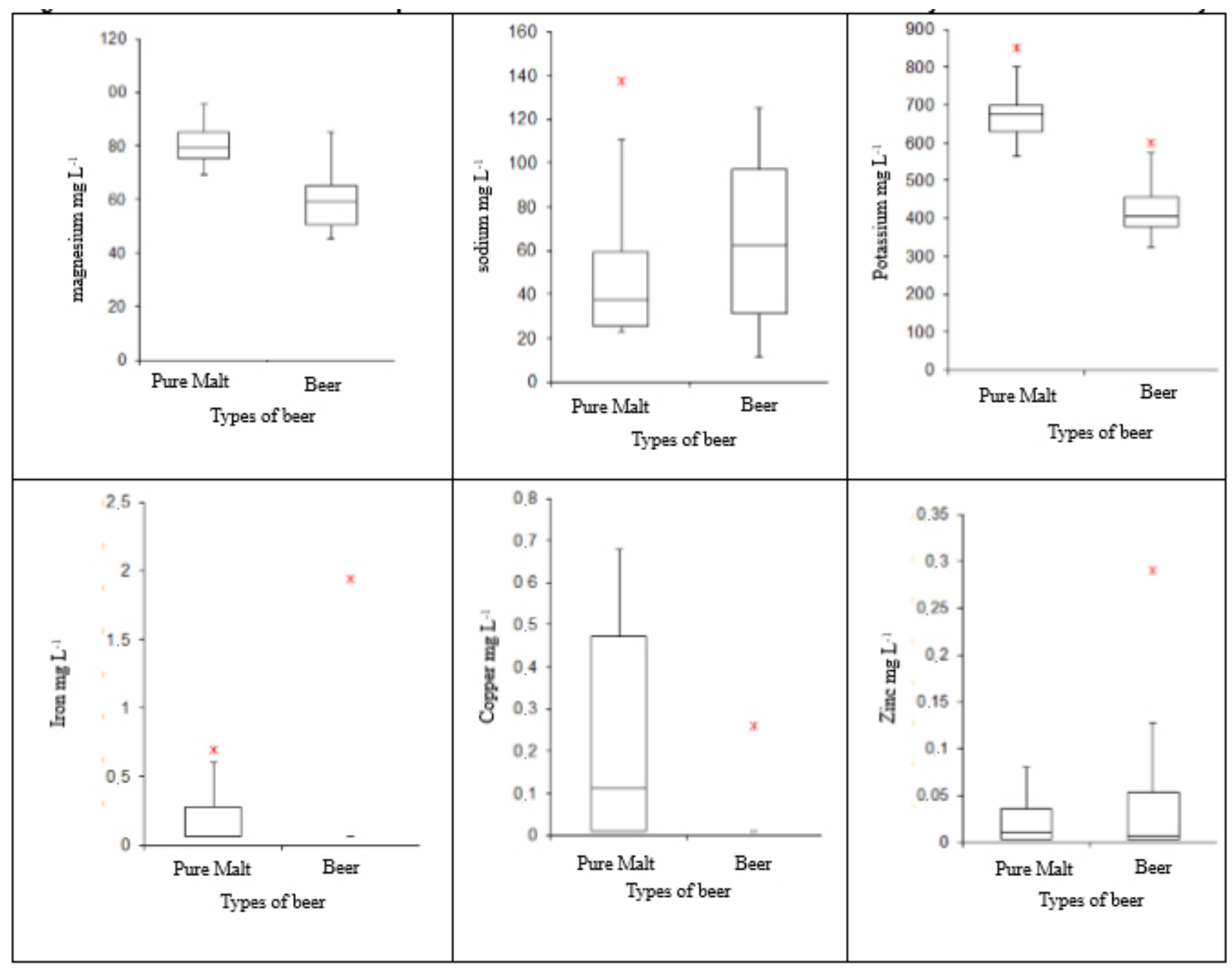

Figure 2. Box-Plot comparative graphs of minerals between samples classified as pure malt and beer. 
non-trained people, this attribute received extreme observations in the comments field of the evaluation form. Some of the comments noted were: "I liked it deeply, but I found it a little bitter. The bitterness could be more emphasized"; "I enjoyed so very much, but it is too bitter!". These extreme comments clearly demonstrate that the evaluation team simulates the perception of a common consumer.

In Figure 3, it can be observed the distribution of concepts assigned in the hedonic scale for each attribute. Appearance and the color presented a higher frequency for "I liked it tremendously". Only the attribute bitterness was mentioned with notes in the negative range of the hedonic scale.

The reason the testers attributed $8.6 / 9$ notes to the appearance attribute may be due to the similarity of beer produced to the reference pattern that exists in their minds, that is, industrial Pilsner type beers.

As for the result of the purchase intention, the vast majority of assessors indicated that would probably buy it (44\%) or would certainly buy it (37\%). None of the tasters expressed they certainly would not buy the product.

\subsection{Multivariate analysis}

The PCA aims to combine chemical descriptors generating a new set of variables called principal components (PCs), which are linear combinations of the original continuous variables, completely independent. The result obtained from the auto scaling with eight factors indicated that, with six major components, cumulative variance was of $99.96 \%$. The first three principal components explain $92.3 \%$ of the total variance, as follows: $\mathrm{PC} 1=51.3 \%, \mathrm{PC} 2=25.5 \%, \mathrm{PC} 3=15.5 \%$. The parcels of the scores were examined and the most informative one is shown in Figure 4, in which two groups can be observed: one of samples classified as pure malt, concentrated in the first quadrant, and one of beers, concentrated in the third quadrant.

In the loadings graph (Figure 5), the influence of variables on the samples is indicated.

Sample 1 (Pós Beer), despite being a beer designed to present pure malt traits, it was formulated so that it was classified as being a light beer, with extract reduction at the time of its production. Real degree of fermentation and apparent degree of fermentation remain closely linked to apparent, real and primal extracts. In addition, this sample was not subjected to pasteurization processes nor filtration. Compared to the rest of the samples classified as pure malt, the sample Pós Beer presented low energy value and lower content of magnesium, which justifies its proximity to the samples classified as beer. On the other hand, two samples classified as beer according to ratio of malted barley were inserted in the pure malt group because of their potassium content. The potassium content in the malt of $518 \mathrm{mg} \mathrm{L}^{-1}$ is much higher compared to the values found in the adjacents (Hutkins, 2007), especially corn grits, which present on average $80 \mathrm{mg} \mathrm{L}^{-1}$ of potassium (Kochrezepte, 2017). In the third quadrant, the most popular beers remained separate from other "beers" (fourth quadrant), on the basis of their sodium levels, which can characterize uniformity in their production.

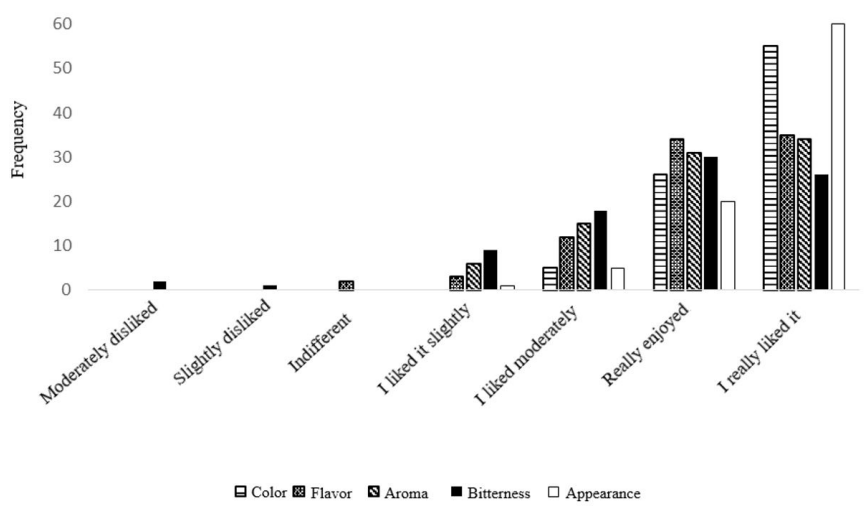

Figure 3. Frequency histogram of grades assigned to the acceptance of the sensory attributes of the craft beer with ginger.

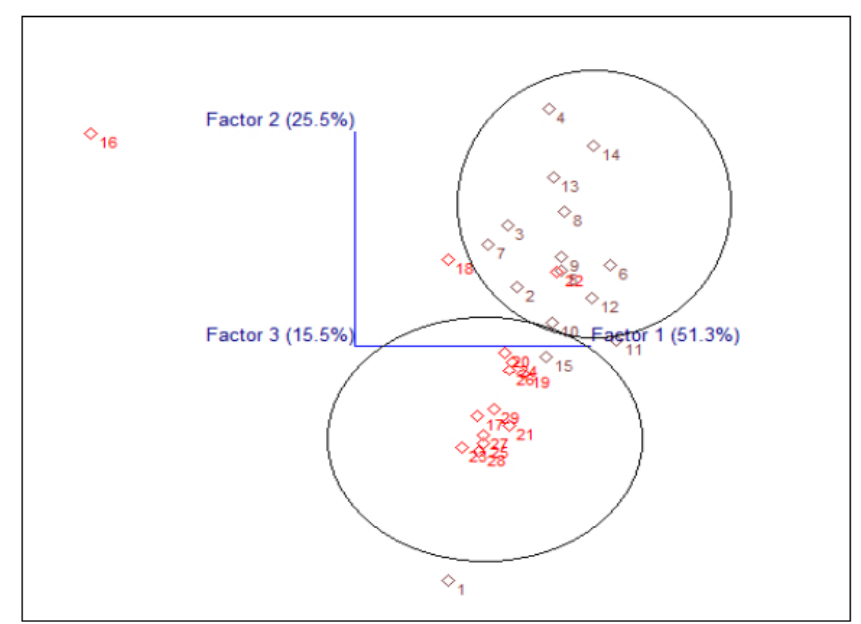

Figure 4. Scores, three-dimensional, auto-scaling, 76.8\% total variance, discrimination of beers according to ratio of barley malt.

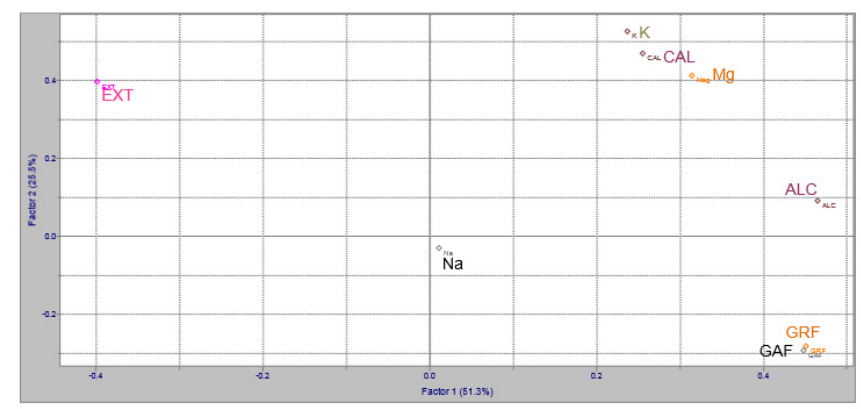

Figure 5. Influence of variables on the samples PC2 X PC1, auto-scaling $\mathrm{X}, 76.8 \%$ total variance, discrimination of beers according to ratio of barley malt. Abbreviations: EXT- apparent extract; Na-sodium; K- potassium; CAL-colories; Mg- magnesium; ALC- alcohol content; GRF-real degree of fermentation; GAF-apparent degree of fermentation.

\section{Conclusion}

It was produced a craft beer with ginger in natura during the step of maturation, with reduced amount of input (malt) and prolonged fermentation with lower temperature than usual. The final product presented low alcoholic content $\left(3.40^{\circ} \mathrm{GL}\right)$. 
During sensory evaluation, the overall acceptability index was $92 \%$, having all remaining attributes assessed (color, taste, aroma, appearance and bitterness) with an index above $70 \%$.

Chemometric analysis indicated that the craft beer with ginger presented similar characteristics to the samples classified as to the proportion of malted barley in beer, in spite of being pure malt, due to levels of alcohol, RDF, ADF, potassium, magnesium and energy value.

This work may contribute to the expansion of knowledge on craft beers, as well as commercial beers. It also enables new manufacturers of craft beer to produce a craft beer with distinct flavor and aroma cause by addition of ginger, approved sensorially by lay consumers.

\section{References}

Alcázar, A., Pablos, F., Martın, M. J., \& González, A. G. (2002). Multivariate characterisation of beers according to their mineral content. Talanta, 57(1), 45-52. http://dx.doi.org/10.1016/S00399140(01)00670-1. PMid:18968603.

Andrade, A. W. L., Lima, E. F. B., \& Meirelles, L. M. A. (2016). Avaliação da rotulagem e qualidade de diferentes marcas de cerveja tipo pilsen. Revista Interdisciplinar, 9(2), 49-56.

Aquilani, B., Laureti, T., Poponi, S., \& Secondi, L. (2015). Beer choice and consumption determinants when craft beers are tasted: An exploratory study of consumer preferences. Food Quality and Preference, 41, 214-224. http://dx.doi.org/10.1016/j.foodqual.2014.12.005.

Brasil. Ministério da Agricultura, Pecuária e Abastecimento. (2009). Regulamenta a Lei no 8.918 , de 14 de julho de 1994, dispõe sobre a padronização, a classificação, o registro, a inspeção, a produção e a fiscalização de bebidas (Decreto $n^{\circ}$ 6.871, de 04 de junho de 2009). Diário Oficial da República Federativa do Brasil.

Brunelli, L. T., \& Venturini, W. G. Fo. (2013). Análise energética de cerveja elaborada com mel. Energia na Agricultura, 28(2), 122-128. http://dx.doi.org/10.17224/EnergAgric.2013v28n2p122-128.

Brunelli, L. T., Mansano, A. R., \& Venturini, W. G. Fo. (2014). Caracterização físico-química de cervejas elaboradas com mel. Brazilian Journal of Food Technology, 17(1), 19-27. http://dx.doi. org/10.1590/bjft.2014.004.

Costa, R. H. K. (2016). Produção de cerveja com baixo teor alcoólico (Dissertação de Mestrado). Escola de Engenharia de Lorena da Universidade de São Paulo, São Paulo.

Dallacort, G. (2013). Curso de formação operador cervejeiro - brassagem (3. ed.). Lages: Ambev.

Dragone, G., Mussatto, S. I., \& Silva, J. B. A. (2007). Utilização de mostos concentrados na produção de cervejas pelo processo contínuo: novas tendências para o aumento da produtividade. Food Science and Technology (Campinas), 27(1), 37-40. http://dx.doi.org/10.1590/ S0101-20612007000500007.

European Brewery Convention. (2005). Analysis committee: analytica - EBC. London: Elsevier.

Ferreira, V. S., Martins, P. K. B., Trindade, J. L. F., \& Tozetto, L. M. (2013). Produção de cerveja artesanal com gengibre. In $8^{\circ}$ Encontro de Engenharia e Tecnologia dos Campos Gerais (pp. 1-9). Ponta Grossa: UTFPR.

Granato, D., Oliveira, C. C., Caruso, M. S. F., Nagato, L. A. F., \& Alaburda, J. (2014). Feasibility of different chemometric techniques to differentiate commercial Brazilian sugarcane spirits based on chemical markers. Food Research International, 60, 212-217. http:// dx.doi.org/10.1016/j.foodres.2013.09.044.

Haniadka, R., Saldanha, E., Sunita, V., Palatty, P. L., Fayad, R., \& Baliga, M. S. (2013). A review of the gastroprotective effects of ginger (Zingiber officinale Roscoe). Food \& Function, 4(6), 845-855. http:// dx.doi.org/10.1039/c3fo30337c. PMid:23612703.

Hutkins, R. W. (2007). Microbiology and technology offermented foods. Victoria: Blackwell Publishing. http://dx.doi.org/10.1002/9780470277515.

Instituto Adolfo Lutz - IAL. (2008). Métodos físico-químicos para análise de alimentos (4. ed.). São Paulo: Instituto Adolfo Lutz.

Keukeleire, D. (2000). Fundamentals of beer and hop chemistry. Quimica Nova, 23(1), 108-112. http://dx.doi.org/10.1590/S010040422000000100019.

Kochrezepte. (2017). Grits (Mineralstoffe) [online]. München: Kochrezepte. Retrieved from http://www.kochrezepte.de/zutat/grits.htm

Kunze, W. (2006). La cerveja terminada. Berlin: VLB Berlin.

Martens, H., \& Naes, T. (1991). Multivariate calibration (1st ed.). Chichester: John Wiley \& Sons.

Matsubara, A. K., Plath, A. R., Barbetta, P. V. C., Ueno, C. T., Moreira, I. C., \& Sakanaka, L. S. (2016). Desenvolvimento de cerveja artesanal de trigo adicionada de gengibre (Zingiber Officinale Roscoe). In AF Oliveira \& LJ Storto (Orgs.), Topicos em ciencias e tecnologia de alimentos: resultados de pesquisas acadêmicas (pp. 21-48). Sao Paulo: Edgard Blücher Ltda. http://dx.doi.org/10.5151/9788580391749-01.

Murray, D. W., \& O’Neill, M. A. (2012). Craft beer: penetrating a niche market. British Food Journal, 114(7), 899-909. http://dx.doi. org/10.1108/00070701211241518.

Nascentes, C. C., Kamogawa, M. Y., Fernandes, K. G., Arruda, M. A., Nogueira, A. R. A., \& Nóbrega, J. A. (2005). Direct determination of $\mathrm{Cu}, \mathrm{Mn}, \mathrm{Pb}$, and $\mathrm{Zn}$ in beer by thermospray flame furnace atomic absorption spectrometry. Spectrochimica Acta. Part B, Atomic Spectroscopy, 60(5), 749-753. http://dx.doi.org/10.1016/j. sab.2005.02.012.

Nascimento, R. F. D., Gavron, A. B., Bowles, S., Chaves, E. S., \& Bortolozo, E. A. F. Q. (2017). Determination of the sodium and potassium levels in meals served in a university restaurant in the south of Brazil. Brazilian Journal of Food Technology, 20, e2016167.

Neilson, H., \& Erdal, K. (2005). The degree of fermentation. Scandinavian Brewers Review, 62(3), 34-35.

Nelson, D. L., \& Cox, M. M. (2014). Princípios de bioquímica de Lehninger. Porto Alegre: Artmed Editora.

Oliveira, G. A. V. D., \& Silva, J. M. S. F. D. (2017). Chemical equilibrium and enzymatic kinetics of $\alpha$-amylase interaction with phenolic compounds found in beer. Quimica Nova, 40(7), 726-732.

Olšovská, J., Štěrba, K., Pavlovič, M., \& Čejka, P. (2015). Determination of the Energy Value of Beer. Journal of the American Society of Brewing Chemists, 73(2), 165-169. http://dx.doi.org/10.1094/ ASBCJ-2015-0322-01.

Peter, K. V. (2006). Handbook of herbs and spices (3th ed.) Cambridge: Woodhead Publishing.

Philpott, J., Taylor, D. M., \& Williams, D. R. (1997). Critical assessment of factors affecting the accuracy of the IoB Bitterness Method. Journal of the American Society of Brewing Chemists, 55(3), 103-106. http:// dx.doi.org/10.1094/ASBCJ-55-0103.

Pinto, L. I. F., Zambelli, R. A., Santos, E. S. Jr., \& Pontes, D. F. (2015). Desenvolvimento de cerveja artesanal com acerola (Malpighia emarginata DC) e abacaxi (Ananas comosus L. Merril). Revista Verde de Agroecologia e Desenvolvimento Sustentável, 10(4), 67-71. http://dx.doi.org/10.18378/rvads.v10i4.3416. 
Ravindran, P. N., \& Babu, K. N. (2005). Ginger: the genus Zingiber. Sri Lanka: CRC Press.

Rebello, F. D. F. P. (2009). Produção de cerveja. Revista Agrogeoambiental, 1(3), 145-155. http://dx.doi.org/10.18406/2316-1817v1n32009224.

Rendall, R., Reis, M. S., Pereira, A. C., Pestana, C., Pereira, V., \& Marques, J. C. (2015). Chemometric analysis of the volatile fraction evolution of Portuguese beer under shelf storage conditions. Chemometrics and Intelligent Laboratory Systems, 142, 131-142. http://dx.doi. org/10.1016/j.chemolab.2015.01.015.

Rio, R. (2013). Desenvolvimento de uma cerveja formulada com gengibre (Zingiber officinalis) e hortelã do Brasil (Mentha arvensis): avaliação de seus compostos bioativos e comparação com dois estilos de cerveja existentes no mercado (Dissertação de Mestrado). Instituto Federal de Educação, Ciência e Tecnologia, Rio de Janeiro.

Schmidt, C., Biendl, M., Lagemann, A., Stettner, G., Vogt, C., Dunkel, A., \& Hofmann, T. (2014). Influence of Different Hop Products on the cis/trans Ratio of Iso- $\alpha$-Acids in Beer and Changes in Key Aroma and Bitter Taste Molecules During Beer Ageing. Journal of the American Society of Brewing Chemists, 2(2), 116-125. http:// dx.doi.org/10.1094/ASBCJ-2014-0326-01.

Serviço Brasileiro de Apoio às Micro e Pequenas Empresas SEBRAE. (2014). Potencial de consumo de cervejas no Brasil: 2014.
Retrieved from http://www.sebraemercados.com.br/wpcontent/ uploads/2015/12/2014_05_20_RT_M ar_Agrn_Cerveja_pdf.pdf

Tan, J., Li, R., \& Jiang, Z. T. (2015). Chemometric classification of Chinese lager beers according to manufacturer based on data fusion of fluorescence, UV and visible spectroscopies. Food Chemistry, 184, 30-36. http://dx.doi.org/10.1016/j.foodchem.2015.03.085. PMid:25872423.

Tohma, H., Gülçin, İ., Bursal, E., Gören, A. C., Alwasel, S. H., \& Köksal, E. (2017). Antioxidant activity and phenolic compounds of ginger (Zingiber officinale Rosc.) determined by HPLC-MS/MS. Journal of Food Measurement and Characterization, 11(2), 556-566. http:// dx.doi.org/10.1007/s11694-016-9423-z.

Tomazoni, T., \& Saviero, J. (2009). Consumo de potássio de idosos hipertensos participantes do Programa Hiperdia do município de Caxias do Sul, RS. Revista Brasileira de Hipertensão, 16(4), 246-250.

Tschope, E. C. (2001). Microcervejarias e cervejarias: a história, a arte e a tecnologia (1. ed.). São Paulo: Aden.

Ubuoh, E. A., Comas, U. C., \& Eze, E. C. (2013). Analysis of metal concentrations in selected canned beers consumed in Owerri Urban, Imo State, Nigeria. International Journal of Material Science, 1, 90-95. 